OPEN ACCESS

Edited by:

Eliza Pinnegar

Independent Researcher, Orem,

United States

Reviewed by:

Elisabete dos Santos Freire, Universidade São Judas Tadeu, Brazi

Luciana Venâncio,

Federal University of Ceara, Brazil

*Correspondence:

Vladimir Martínez-Bello

vladimir.martinez@uv.es

Specialty section:

This article was submitted to

Teacher Education,

a section of the journal

Frontiers in Education

Received: 23 May 2020 Accepted: 19 October 2020

Published: 11 November 2020

Citation:

Martínez-Bello V, Martínez-Rojas Á and Lahuerta-Contell S (2020) A

Critical Analysis of the Explicit and Implicit Treatment of Human Rights Education in Early Childhood

Education Textbooks.

Front. Educ. 5:565139.

doi: 10.3389/feduc.2020.565139

\section{A Critical Analysis of the Explicit and Implicit Treatment of Human Rights Education in Early Childhood Education Textbooks}

\author{
Vladimir Martínez-Bello ${ }^{1,2 *}$, Ángela Martínez-Rojas ${ }^{3}$ and Sara Lahuerta-Contell ${ }^{3}$ \\ ${ }^{1}$ Department of Teaching of Musical, Visual and Corporal Expression, University of Valencia, Valencia, Spain, ${ }^{2}$ COS \\ Research Group, Body, Movement, Music and Curricular Practices, University of Valencia, Valencia, Spain, ${ }^{3}$ Independent \\ Researcher, Valencia, Spain
}

The United Nations Convention on the Rights of the Child explicitly recognizes that children are entitled to the full range of civil, cultural, economic, political and social rights. Despite the powerful social function of textbooks in legitimizing cultural norms in primary and secondary education, there has been little attention on human rights issues in early childhood education (ECE) curricular materials. Therefore, this study aims to analyze the explicit and implicit representation of human rights education (HRE) in ECE textbooks. Our quantitative and qualitative results show that ECE textbooks failed to find any explicit mention of children's rights, an excessive attention focused on the teaching of responsibilities, a distorted representation of childhood, a lack of representation of those responsible for children's rights, a justification to avoid the adults' loss of power, and the idea that teaching children as citizens with rights constitutes inappropriate politicization of the school. Evaluating how human rights are taught in curricular materials is crucial. These results can also be transferred to other scenarios and processes in the ECE classrooms.

Keywords: human rights education, early childhood education, textbooks, children's rights, curricular materials

\section{INTRODUCTION}

The United Nations Convention on the Rights of the Child (United Nations, 1989) explicitly recognizes that children are entitled to the full range of civil, cultural, economic, political and social rights. The Committee on the Rights of the Child (United Nations, 2006) reaffirms the need to apply the Convention holistically in early childhood, taking into account the universality, indivisibility and interdependence of all human rights. In the educational context, different international organizations have formally articulated their awareness of these rights: the UN General Assembly has adopted the United Nations Declaration on Human Rights Education and Training (UNDHRET) (United Nations, 2011), while the Council of Europe has adopted the Charter on Education for Democratic Citizenship and Human Rights Education (EDC/HRE) in the framework of Recommendation CM/Rec(2010)7. 
The concept of human rights education (HRE) has evolved in recent decades. Recognizing that understanding of HRE depends on the social and cultural environment (Bajaj, 2011), scholars have developed a three-dimensional model for its analysis: education "about," "through," and "in/for" human rights. Lohrenscheit (2002) perceives the dimension "about" as referring to cognitive knowledge. That is, HRE transmits information about human rights, identifies other ways to share this information, and creates skills and competencies for active citizenship (Flowers, 1998). The dimension "through" raises awareness of the actors involved by means of the teachinglearning process (Mihr, 2004), and teaching this dimension can serve to achieve complementary ends to the spirit of human rights (Bajaj, 2011). Finally, the dimension "in" focuses on actively empowering individuals to detect injustices, inequalities, and violations of human rights (Ely-Yamin, 1993; Meintjes, 1997; Tibbitts, 2002; Mihr, 2004).

If the curriculum is understood to be a social construction (Gimeno-Sacristán, 1991), teachers and practitioners must identify how curricular practices have the capacity to construct, modify, recreate and transmit meanings. In the early childhood education (ECE) context (3- to 6-year-olds), Woodrow and Press (2007) have pointed to the importance of identifying the contemporary views of childhood and how these are embedded in the daily practices and policy frameworks of the ECE and care fields. In other words, the sociology of childhood theoretically strengthens the claim that children are legitimate humans and holders of human rights (Quennerstedt, 2016). As HRE at preschool is more than a mere reading about human rights, teachers must pay more attention to what they do than to what they say (Abdallah-Pretceille, 1991). Therefore, adults involved in ECE (teachers, practitioners and families) cannot limit their discussions to children's learning alone; they must also rolemodel the relations and ideologies they aim to transmit to children amongst themselves (Sánchez-Blanco, 2000).

In the research community, HRE is in a phase of initial formation between theory and its interaction with other discourses in the classroom (Suarez, 2007; Bajaj, 2011; Quennerstedt, 2016). The development of a closer dialog between HRE and other areas of education, in this case ideology critiques and their exercise in ECE context, will contribute to clarifying values and concepts, as well as to identifying contradictions and superficial tendencies.

Under the United Nations (1989), signatory States must raise awareness of children's rights in addition to respecting them. However, Robinson (2012) argues that adults have heavily regulated children's education and access to information through institutions such as schools, strictly defining what knowledge children should and should not be privy to. On training in aspects of teacher ideology critiques, Brown (1998: 50) suggests that this process "involves making decisions about what to teach, how to teach, when to teach. What criteria do we use when selecting books, toys and other learning resources?" For their part, Gollob and Krapf (2007) urge teachers to carefully select curricular materials and decide which methods to use in the classroom.

Textbooks are considered central means of learning. Composed of text and images, they function as key educational tools that guide the construction of the school curriculum (Montagnes, 2000; Brugelles and Cromer, 2009), and they reproduce the authoritative facts and values that children should learn, as mediated by teachers (Tomaševski, 2001). In this sense, as Giroux (1983) suggests, the teaching staff must "[p]ay close attention to those basic, tacit and constitutive rules that establish the most obvious factors of classroom choices." As Quennerstedt and Quennerstedt (2014) see it, researchers need to apply a rights perspective to analyze educational activities in early childhood settings and in schools.

Due to the scarce evidence on how HRE is represented in ECE textbooks, our literature review addressed this aspect in secondary and primary school textbooks and in the international and Spanish context. Internationally, Meyer et al. (2010) examined the presence of HRE in secondary school social science textbooks from 1970 to 2008, observing a clear evolution over three periods. The same authors analyzed how textbooks from 74 countries represented the active role of childhood and adolescence in discussions of human rights (Bromley et al., 2011). Aslan and Karaman-Kepenekci (2008) found that Turkish books deal with HRE more than French books, while Unal (2013) found that primary school textbooks contained scant mention of the rights to life, decent living standards, medical assistance and adequate nutrition. Other authors, such as Weinbrenner and Fritzsche (1993) analyzed German textbooks, observing that HRE often "hides" behind other issues and that textbooks traditionally discuss human rights from an ethnocentric perspective. Finally, Garnet-Russell and Tiplic (2014) examined a sample of secondary school history, social studies and civics textbooks, finding that both the presence of inter-group conflicts and the level of democracy of the countries analyzed have an impact on the discourse on rights constructed in textbooks within each country.

In Spain, Messina et al. (2016) assessed high school citizenship textbooks (in Spanish and English) to analyze the representation of knowledge, participation in civic life and commitment to pluralism. The authors noted that Spanish textbooks tend to focus attention mainly on moral issues, while English textbooks emphasize social responsibility. López Atxurra and Caba Collado (2003) analyzed how human rights content is presented in four environmental knowledge textbooks in the Basque Country. Although the official curriculum indicates the importance of these contents in curricular materials, just two of the textbooks explicitly presented human rights, and they did so only toward the end of primary school.

Despite the powerful social function of early years textbooks and curricular materials in legitimizing cultural norms, values and knowledge (Martínez-Bello and Martínez-Bello, 2016; Martínez-Bello et al., 2019) and their curricular power to transmit meanings in primary and secondary education, there has been little attention on human rights issues in ECE materials. Shafer (1987) signaled that classrooms are true sites of human rights practice, and critically analyzing the treatment of human rights in curricular materials constitutes a commitment to know, value, reconstruct and later incorporate these conclusions into ECE teacher training. As little research has considered the role of education for children's and young people's growth as rights holders (Quennerstedt and Quennerstedt, 2014), this study aims 
to analyze the explicit and implicit representation of HRE in Spanish ECE textbooks published from 2006 to 2013.

\section{METHODOLOGY}

\section{Sample}

The sample consisted of textbooks that are part of the second ECE cycle, a period roughly corresponding to ages 3 to 6 years. Textbook series from the following three publishing houses were analyzed: Anaya (iQué Idea! [What an Idea!]), Edelvives (Dimensión Nubaris) and Santillana (Mica y sus Amigos [Mica and her Friends]). Approximately 20 textbooks (5 to 9 per publisher) were analyzed for each age group. Inclusion criteria were textbooks: categorized as the core curriculum taught to all children from ECE levels 1 to 3 (3 to 6 years old); in current use by public and private early childhood schools; published in Spain by the top 20 publishers in the Spanish education sector; written in Spanish and covering all three levels of ECE; applying an integrated model called globalized material; and published following passage of the 2006 Organic Law of Education (2006-2013).

\section{Selection of Units of Analysis}

The units of analysis were phrases in the headings, subheadings and paragraphs in which activities are introduced in the textbooks. The units came from 60 different textbooks, including 20 for each ECE level. A total of 620 units were subjected to quantitative and qualitative analysis.

\section{Data Analysis \\ Quantitative Analysis}

For the quantitative data, the analysis was restricted to the written text. Before undertaking the definitive analysis, we interviewed a group of experts (professors of human rights) in order to understand how to investigate HRE in curricular materials. The quantitative analysis was done by the first author who had received training on the categories and indicators prior to the definitive analysis. Following this training, we proceeded to the definitive analysis of the images and the quantification of the data obtained. A system of categories and indicators were constructed post hoc. The categories were: rights/responsibilities, age/level, and types of responsibilities.

First, each page of the textbook was examined to identify explicit mentions of HRE, such as: "HRE," "children's rights education," "human rights," "rights of girls and boys," "rights," "fundamental rights," "social, political and cultural rights," "citizenship education," etc. A second search was then carried out for key words such as "rights and duties" and "responsibilities," as well as the explicit and implicit representation of international instruments, with words like "Declaration," "Convention," and "Laws," as well as more expressive instruments in phrases such as "Universal Declaration of Human Rights," "United Nations Convention on the Rights of the Child," "Political Constitution," and others with similar characteristics. Finally, we conducted a search to identify "duties," "norms," and "responsibilities" that were reflected in the written text of any page of the textbooks analyzed.

\section{Qualitative Analysis}

Following the quantitative analysis, we proceeded to perform a qualitative analysis according to general guidelines of discourse analysis proposed by Fairclough (2001), who stated that the producer of a text constructs it as an interpretation of the world, according to the predominant social norms that govern it. Thus, this type of analysis assigns meaning to the literal representation of the statement, based on the recognition of aspects indicating that school is not a politically neutral setting. The qualitative analysis was meant to complement the quantitative analysis, providing a more complete vision of how HRE is conceived in the textbooks.

Data were transcribed in a Word document. Critical qualitative analysis of the transcript was performed by coding and then classifying each unit of analysis. The categories were derived from the data, based on the detection of common elements. We followed the three stages Fairclough (2001) proposed for discourse analysis: description, interpretation and explanation. The descriptive phase started with a general reading of each textbook; we then proceeded to select units of meaning through a more specific reading, selecting phrases that presented activities and stories, based for example on some of the following words and phrases: "Using correctly"; "That is not safely"; "Who has not respected the signal?"; "The sign of forbidden"; "Happy if he acts correctly and sad if he does not"; "Sad faces where the rules are not being followed"; "Correct seats"; "That is not the right use"; "Respect"; "How should we behave"; "They are behaving well"; "They are acting badly"; "According to whether the actions are correct or not"; "Correctly protected"; "to take precautions"; "Those who comply"; "Those who do not comply."

For the qualitative data, the analysis was restricted to the written text, although the images accompanying the text were also examined for contextual understanding. When necessary, the analysis was accompanied by a reflective reading about the relationship of the image accompanying the written text. The units of analysis with the previous indications were transcribed again in a Word document, and the following elements were marked in red: the main subject of the action; the action or situation that the subject must perform or abstain from performing; the presence and relationship of visual representations with the subject and with the action; the beneficiary or beneficiaries of the action or abstention. Likewise, when possible, authority figures were identified as elements of control and sanction, within the commission or omission of the situations described in the text. Finally, once the description and interpretation of the previous statements was made, the conditions of the actions, omissions and actors were linked to the purposes of HRE. For this, we identified the holder of the right or the person responsible for the action, reflecting critically on how their treatment in the textbook constructs the concept of childhood and the learning and exercise of children's human rights. To obtain a measure of reliability for the coding, two investigators independently analyzed the data. Once each of the categories was identified, the other investigator corroborated 
them. The data from the qualitative analysis were coded into initial categories, after which a joint review by both investigators produced a smaller and definitive list.

\section{Statistical Analysis}

In the quantitative analysis, a descriptive analysis was used to represent the main categories (\%).

\section{RESULTS}

\section{Quantitative Analysis}

None of the analyzed textbooks from any of the three publishing houses contained an explicit mention of HRE.

With regard to the types of responsibilities taught to the children, Figure 1 shows that "Environmental care" led the ranking at $24 \%$, followed by "Road safety" at $16 \%$, and "Healthy habits" and "Good behavior" with 15\% and 14\%, respectively. The indicators "Manners," "Dangerous situations," and "Animal care" corresponded to $10 \%, 8 \%$, and $6 \%$ of the responsibilities taught, respectively. The rest of the indicators had a presence of $5 \%$ or less.

With regard to the age when topics related to responsibilities were taught (Figure 2), nearly half of these lessons were covered at age 5, or ECE level 3 (48\%). In contrast, $30 \%$ of the total responsibilities taught were introduced at age 3 (ECE level 1), and $22 \%$ at age 4 (ECE level 2).

\section{Qualitative Analysis}

We triangulated the quantitative and qualitative results to more fully describe the context and facilitate reflection on the representation of HRE in the ECE textbooks. Table 1 shows the results of the coding tree elaborated during the analysis.

\section{Lack of Explicit Representation of Human Rights}

The UNCRC explicitly recognizes that children are entitled to the full range of civil, cultural, economic, political and social rights. The UNDHRET (United Nations, 2011) affirms that all people (including children) have the right to know, seek and receive information about human rights and fundamental freedoms and should therefore have access to training and HRE (art. 4).

However, our quantitative analysis reveals that this information is scarce to non-existent in the curricular materials analyzed. Indeed, there was no explicit information on human rights or even an allusion to the most basic international instruments where these rights are collected, for example, the UNCRC (United Nations, 1989) or the Spanish Constitution. This is despite the fact that the Law ECI/3960/2007 (SPAIN, 2007) makes a specific point to link the curricular materials in the ECE classroom to HRE: "The selected materials must reflect and encourage respect for the principles, values, liberties, rights and constitutional duties."

One possible explanation for this omission is the tendency to not recognize children's capacity to build their own identity (Smith, 2013). At this educational level, girls and boys are perceived as too young to know and understand vital elements, such as the norms that govern a group, both at the micro-local level and in the classroom. These could well be referents of a "set of rules" built by all, such as a State constitution or an international treaty.

\section{Excessive Attention Focused on the Teaching of Responsibilities}

The relationship between rights and responsibilities is central to the tenets of HRE for children. Strictly speaking, learning and exercising rights also involves responsibilities, and these must coexist harmoniously. Children receive guidance from textbooks regarding environmental care, road safety, healthy habits and manners at all ages (although with some variability by educational level). However, ultimately these responsibilities are not framed as a counterpart (or better yet, complement) of human rights. This is apparent in the following excerpt:

"Stick paper balls on the clothes of the character who is using the trash correctly.

Color a sad face on the character that does not keep the street clean.

Place the sticker of a sad face on the character that is not moving around safely.

Place the sticker of a sad face on the character that is not moving around safely."

The activities are mainly aimed at teaching the child to recognize whether the picture depicts someone performing the action correctly. In the same way, some sentences link the determination of those correct and incorrect behaviors to visual "signals" through which said behavior is prohibited.

"Place the stickers of the sad face on the character who has not respected the signal.

Mark with thick crayons the sign of forbidden fire.

Place the right face sticker on each picture: happy if they behave well and sad if they do not.

Search and circle the posters of the bus rules. Place stickers of sad faces where the rules are not being followed."

We agree with Waldron and Oberman (2016) that activities like these are concerned with child stewardship rather than child rights per se and will therefore by their nature project responsibility over entitlement. This misinterpretation of the scope of children's rights correlates to a low application of their teaching. Howe and Covell (2010) argue that teachers' reluctance to teach human rights leads them to direct their attention toward the teaching of responsibilities. On the role of schools in promoting HRE, Le Gal (2008) affirms that children have to learn about their rights by exercising them. However, the textbooks analyzed focus preferentially on teaching responsibilities, regardless of the educational level, and they rely primarily on the constructs of "You must" or "You should not" (Le Gal, 2008).

When comparing the UNCRC (United Nations, 1989) with Recommendation 1401 on education in individual responsibilities (Council of Europe, 1999), there is a similarity in the spirit of the two instruments, if not in the form. The United Nations (1989) recognizes responsibilities from the direct 

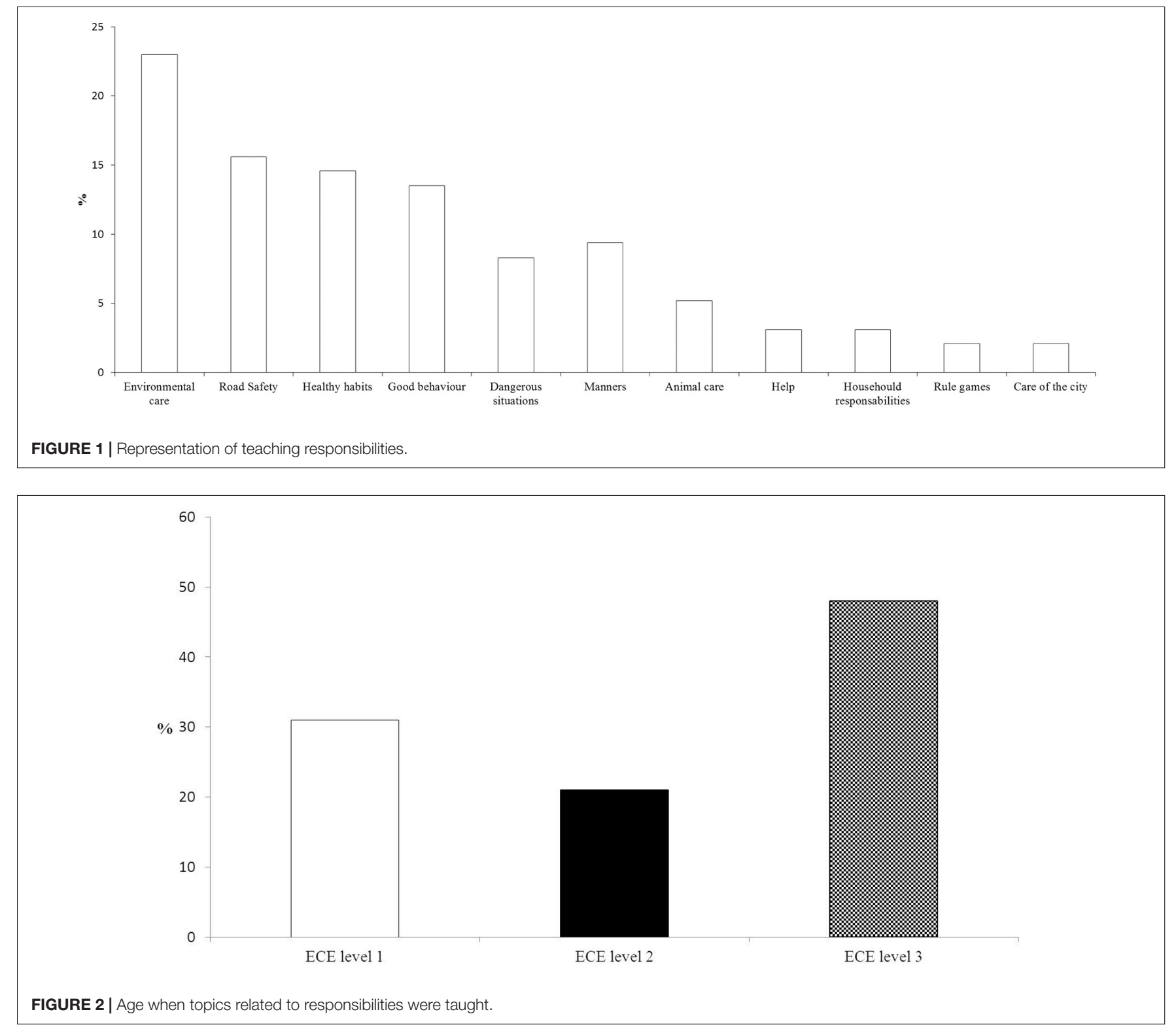

perspective of respect for human rights; article 29 stipulates that education should be aimed at "inculcating the child's respect for human rights and fundamental freedoms and the principles enshrined in the United Nations Charter." In this sense, Gil et al. (2001) suggest that rights and duties are two sides of the same coin: human beings are both holders of rights and people who are capable of assuming duties and obligations toward themselves and others. In other words, they have the responsibility to respect the rights of others.

A contrasting argument, put forward by Recommendation 1401 of the Parliamentary Assembly (Council of Europe, 1999) and other sectors of the doctrine, is that it is unnecessary to focus attention on teaching responsibilities. Rather, education can directly use the framework of HRE to promote respect for human rights and, consequently, promote responsibilities. Merrigan (2014) noted that the argument in favor of teaching responsibilities underpins the need for education in individual responsibility, and this is a necessary complement to knowledge and skills around the human rights framework. However, this author argues that the education of individual responsibility must be nested within the framework of human rights or HRE, not vice versa or outside of that framework.

There is a common belief among many adults, but especially teachers, practitioners and families, that children have too many rights and not enough responsibilities (Cassidy et al., 2014). In fact, Waldron and Oberman (2016) found that teachers recognize the importance of HRE but are more focused on promoting a culture of conformity and responsibility. Howe and Covell (2010) similarly noted that charging children with a set of obligations rather than rights constitutes miseducation. We agree with Howe and Covell (2010) that the focus on responsibilities 
TABLE 1 | Categories from the qualitative analysis

\begin{tabular}{|c|c|}
\hline \multicolumn{2}{|c|}{ Categories } \\
\hline Initial categories & Definitive categories \\
\hline $\begin{array}{l}\text { - Inexistence of human rights } \\
\text { - Omission of regulatory provisions }\end{array}$ & $\begin{array}{l}\text { Lack of explicit representation } \\
\text { of human rights }\end{array}$ \\
\hline $\begin{array}{l}\text { - No human rights, but teaching } \\
\text { responsibilities } \\
\text { - Explicit teaching of responsibilities } \\
\text { - Respect for knowledge of the } \\
\text { environment and the rules }\end{array}$ & $\begin{array}{l}\text { Excessive attention focused on } \\
\text { teaching of responsibilities }\end{array}$ \\
\hline $\begin{array}{l}\text { - Omission of the State's responsibility to } \\
\text { protect rights } \\
\text { - Individual responsibility } \\
\text { - The construction of local citizenship }\end{array}$ & $\begin{array}{l}\text { Lack of representation of those } \\
\text { responsible for children's rights }\end{array}$ \\
\hline $\begin{array}{l}\text { - Treatment of human rights threats or } \\
\text { violations } \\
\text { - Awareness of human rights threats and } \\
\text { violations }\end{array}$ & $\begin{array}{l}\text { Treatment and awareness of } \\
\text { threats or violations of human } \\
\text { rights }\end{array}$ \\
\hline - The distorted representation of childhood & $\begin{array}{l}\text { The politicization of childhood } \\
\text { and the need to teach human } \\
\text { rights in the "neutral school" }\end{array}$ \\
\hline & $\begin{array}{l}\text { Themes not addressed by the } \\
\text { textbooks }\end{array}$ \\
\hline
\end{tabular}

dilutes the importance of rights but gives teachers ways to manage behavior.

Despite the absence of any explicit representation of human rights in the textbooks analyzed, there are some manifestations in which the "about" dimension of rights is present. This is the case of lessons that encourage children to resolve conflicts peacefully. As Flowers (1998) and Fortat and Lintaf (1989) suggest, the dimension "about" human rights can be taken to the classroom, for example, by encouraging respect for the opinions of others, even if the right to freedom of expression and the obligation to respect that right in others is not explicitly presented as such. This is illustrated by one of the registration units we observed: "Go ahead and say what worries you and interests you. Your opinion is important. Can all children participate?"

Similarly, ECE classrooms work on the concept of understanding sets of small rules that regulate curricular practices in children's classrooms, and that, among other things, these have the purpose of maintaining the common well-being. On rare occasions, textbooks invite knowledge about a right (in the case above, the right to freedom of expression), although this is usually not done explicitly. Instead, the reader must decipher the message. The phrase "Your opinion is important," implies a degree of seriousness so that the child becomes aware of the importance of expressing ideas. In this case, the resource is direct and aimed at developing the child's capacity to exercise their right (not only to know that they have it) by expressing their opinion. Moreover, the adult serves as a witness to the exercise of that right and an authority who can channel the concerns and interests. On the contrary, the textbook has chosen to tailor the attribute of the right (in this case, the right to freedom of opinion and expression) to the child who reads or will work with the text. This is one of the few clear examples that is not neutral and is moderately direct, in which knowledge and the way to exercise a human right is taught. Thus, we can conclude positively that textbooks do work on this right, as stated in the UNCRC (United Nations, 1989) and clarified in the Committee on the Rights of the Child with General Comment 7 (United Nations, 2006).

\section{Lack of Representation of Those Responsible for Children's Rights}

The UNCRC is an agreement between States that articulates their obligations toward their citizens. Article 5 recognizes the obligation on State parties to provide assistance that includes quality childcare services. As signaled by Roose and BouverneDe Bie (2007), the UNCRC implies a fundamental commitment to ensuring the educational conditions required, not only of parents but also of society as a whole, for every child's adequate development. A crucial role in guaranteeing young children's rights is played by their parents, along with other members of family, extended family or community, including legal guardians, as appropriate (United Nations, 2006). In this sense, a positive manifestation of care and affection is apparent in the other unit of analysis: "Put red stickers on the scenes where the family gives affection and green ones where the family cares."

However, we also found another type of discourse, illustrated in the next unit of analysis:

"Look at the photograph and see how the garbage is recycled." "On his field trips, Suso has seen that most children are careful with plants, but there are some who are not: Are you careful with plants?"

"Circle the children who are properly protected and draw a happy face in their boxes. Cut out the things that children need to be protected and paste them where appropriate."

The obligation and responsibility to exercise and ensure rights (in this case, the right to protection and health) depends primarily on the family and secondly on the State. However, in this example, children are expected to know that there is a way to be protected when it is cold, but who should be in charge of protecting them is left to their imagination. Thus, the individualization of responsibility (as an excuse for the teaching of rights) could prevent children from learning that adults are responsible for guaranteeing children's free exercise of their rights. For instance, in terms of recycling, or better still in terms of large-scale environmental pollution, children could be learning that adults and some institutions, especially public ones, must protect the health of the environment. Likewise, a decent, warm home and season-appropriate clothing are the responsibility of families or public services-anyone but the children themselves. Alderson (1999) reported similar findings. This new discourse is one in which the teaching of responsibilities is left in a vacuum or is directed at girls and boys, but not at adults and at institutions. We agree with Roose and Bouverne-De Bie (2007) that the debate on children's rights should focus not so much on the rights children have or do not have but rather on the question of how the rights of children are to be realized. 
In addition, Article 42 of UNCRC (United Nations, 1989) calls on State parties to raise awareness of the principles and provisions of the Convention. That is, for the States, and particularly for the educational systems, HRE becomes an obligation. As Howe and Covell (2010) put it, it is not enough that children have basic rights, they also have to know that they have rights. Our findings are suggestive of non-compliance of these provisions. We consider that this treatment stems from a lack of recognition of children's capacity to build knowledge of themselves and others, and a disregard for the fact that children's exercise of their rights depends to a large extent on adults and the State.

\section{Treatment and Awareness of Threats or Violations of Human Rights}

For a substantial sector of HRE doctrine, raising awareness about threats and violations of human rights is an important dimension to understanding the concept (Flowers, 1998). In this regard, we did not find any explicit examples of possible threats or violations of human rights in our analysis of the textbooks. We consider that this omission avoids recognizing both the existence of the right and the situations that may impede the exercise of rights. Indeed, awareness is necessary to recognize inequality and to position a subject as being emancipated from it. However, the examples we found in relation to the right to physical and mental integrity are presented only in the form of receiving care, for example, if an injury occurs as a result of an accident (usually due to the lack of compliance with the rules of behavior). In this case, the person who can help is shown, as well as the professional who is responsible for their treatment. This is indicated by the following registration units:

"Who takes care of our health? Healthcare professionals. Today Suso has gone to a dental checkup. What doctor will he have to go to?

Mark the box of the doctors that you have ever visited."

Finally, we found no depictions of situations of psychological violence, which can undermine the right to well-being and personal integrity. For Ely-Yamin (1993), the great promise that HRE has in terms of empowering people, not only to defend, but also to claim their rights, raises serious questions about how to frame a pedagogical program. In this context, the Vienna Declaration and Program of Action (United Nations, 1993) affirmed that HRE "must embrace peace, democracy, development and social justice in order to achieve understanding and awareness of all about human rights." More recently, the United Nations (2011) specified that HRE should "[c]ontribute to the prevention of abuses and violations of human rights and. combat and eradicate all forms of discrimination and racism." In our study, the absence of any explicit examples of how to prevent violations of human rights suggests that there is no space for developing this awareness.

\section{The Politicization of Childhood and the Need to Teach Human Rights in the "Neutral School"}

An obstacle that could explain the distorted representation of human rights in the textbooks analyzed is related with an attempt to protect children from politicization both inside and outside the school (Kulynych, 2001; Howe and Covell, 2005). The promoters of the political "neutrality" of the school encourage the construction of a passive identity for teachers, families, and students. The curriculum is thus pre-limited to avert ideological disputes, thereby continuously hindering children's reflective development toward citizenship. By contrast, Sánchez-Blanco (2000) argues, "This contextualization requires an analysis in ECE of the influence of the sociopolitical, cultural and economic context of the curricular practices of the Stage." In other words, school is not and cannot be a neutral space.

A first set of obstacles to the incorporation of HRE is related to the traditional representation of children. From this perspective, children are not in a position to exercise their rights because their evolutionary status prevents them from understanding and making rational decisions. That is to say, a "childish, immature, innocent and unprepared" conception of childhood has been perpetuated in the current discourse, despite recognition as early as 1978 by the special rapporteurs at the International Congress of HRE that attitudes regarding human rights begin in early childhood. On the other hand, Beiter (2005) argued that child-centered education must contribute to the construction of a critical conscience, capable of reflecting on the distorted meanings that generate discrimination and injustice and that, for example, are present in curricular materials. As a critique for this “innocence representation," Quennerstedt (2016) suggest that romanticizing and naturalizing views of young children and childhood may lead us to assume that power structures do not apply to practices involving very young children. As Bailey (1994) put it: "It's more difficult, still. This requires programs that empower children by treating them as individuals, listening to them and motivating the negotiations of meanings and intentions through offering opportunities for them to ensure control of their own learning."

\section{Themes Not Addressed in the Textbooks}

An interesting result of our analysis of textbooks was the omission of some topics in the school curriculum, identified as "null curriculum-null curriculum." In this sense, Freire (2012) states that education stops looking for emancipation when it becomes a "banking education," in which children periodically receive "deposits" of information but without criticizing or analyzing it. For example, there was an absence of representation on education for sexuality in the textbooks analyzed, even though both international and private organizations have issued guidelines for the treatment of sexual rights in children (United States, 2004; International Planned Parenthood Federation European Network, 2006) and their close connection with respect for human rights. Robinson (2012) suggested that it is critical that children have access to open, well-informed honest discussions around sexual knowledge that respect children's agency and build their resilience and competencies in this area. Furthermore, although the UNCRC asserts that children have the right to be protected from any type of abuse that undermines their personal integrity (including physical, sexual and psychological), the textbooks analyzed do not talk about this right, about consent, or about how to report inappropriate behavior. We agree with Robinson (2012) that censorship around 
children's access to sexual knowledge, in the name of protection, is ironically contributing to children's vulnerabilities on many different levels.

\section{Limitations and Future Research}

Our study is a first approximation of how ECE curricular materials represent HRE. Future research is necessary to explore how HRE is practiced in ECE classrooms. For example, new studies could assess the entire process of creation, implementation and evaluation of curricular materials, or investigate how children negotiate the meanings of their human rights in curricular materials. A crucial question is how children assign meaning to different representations of their human rights in their textbooks. Furthermore, taking into account that we know little about the representation of human rights in the broad range of textbooks available to children aged between 3 and 6 years old throughout Latin-America, future studies could elucidate this issue. Notwithstanding these pending questions, our study, as the first of its kind in the context of ECE, is an opportunity to continue the debate on how teachers and practitioners in ECE could perform a critical analysis of the curricular materials.

\section{CONCLUSION}

Children's rights can only be taught insofar as young children are recognized as both holders of rights and as human beings who are competent enough to exercise them. Although the normative and doctrinal sphere affirms that children have the right to receive information about their human rights, our analysis of ECE textbooks failed to find any explicit mention of children's rights, as defined in the main international legal instruments included under the Spanish constitution. Our interdisciplinary

\section{REFERENCES}

Abdallah-Pretceille, M. (1991). "Human rights in the Nursery School," in The Challenges of Human Rights Education, ed. H. Starkey (London: Cassell).

Alderson, P. (1999). Human rights and democracy in schools do they mean more than "picking up litter and not killing whales"? Int. J. Child. Rights 7, 185-205. doi: $10.1163 / 15718189920494336$

Aslan, C., and Karaman-Kepenekci, Y. (2008). HRE: a comparison of mother tongue textbooks in Turkey and France. Mediterranean J. Educ. Stud. 13, 101-124.

Bailey, K. (1994). The girls are the ones with the pointy nails: an exploration of children's conceptions of gender. Resour. Feminist Res. 23, 50-51.

Bajaj, M. (2011). HRE: ideology, location, and approaches. Hum. Rights Q. 33, 481-508. doi: 10.1353/hrq.2011.0019

Beiter, K. D. (2005). The Protection of The Right to Education by International Law: Including a Systematic Analysis of Article 13 of the International Covenant on Economic, Social and Cultural Rights. Leiden: Brill. doi: 10.1163/ ej.9789004147041.i-738

Bromley, P., Meyer, J. W., and Ramirez, F. O. (2011). Student-centeredness in social science textbooks, 1970-2008: a cross-national study. Soc. Forces 90, 547-570. doi: 10.1093/sf/sor004

Brugelles, C., and Cromer, S. (2009). Promoting Gender Equality Through Textbooks. A Methodological Guide. Paris: United Nations Educational, Scientific and Cultural Organization. treatment and interpretation of data did identify other elements, such as the reluctance to teach children about their rights; insufficient knowledge of these rights; a distorted representation of childhood; a justification to avoid the adults' loss of power; and the idea that teaching children that they are citizens with rights and how they can exercise them constitutes inappropriate politicization of the school setting.

Our analysis of the data indicates that knowledge of rights focuses on learning responsibilities (for example, not littering, recycling), but this is disconnected from an awareness favoring the acquisition of skills or competences. Children are treated as competent enough to understand certain types of content and information, but insufficiently prepared to be taught aspects related to the human rights in general and their entitlement to these rights in particular. Evaluating how human rights are taught in curricular materials is crucial. These results can also be transferred to other scenarios and processes in the ECE classrooms.

\section{DATA AVAILABILITY STATEMENT}

The raw data supporting the conclusions of this article will be made available by the authors, without undue reservation.

\section{AUTHOR CONTRIBUTIONS}

VM-B and ÁM-R contributed to the design and implementation of the research, the analysis of the results, and the writing of the manuscript. SL-C contributed to the analysis of the results and the theoretical framework. All authors contributed to the article and approved the submitted version.

Cassidy, C., Brunner, R., and Webster, E. (2014). Teaching human rights? All hell will break loose!'. Educ. Citizenship Soc. Justice 9, 19-33. doi: 10.1177/ 1746197913475768

Council of Europe (1999). Recommendation Education in the responsibilities of the individual 1401. Parliamentary Assembly (30 March. EC Doc. 8283). Strasburg: Council of Europe.

Ely-Yamin, A. (1993). Empowering visions: toward a dialectical pedagogy of human rights. Hum. Rights Q. 15, 640-685. doi: 10.2307/762401

Fairclough, N. (2001). Language and Power. London: Pearson Education.

Flowers, N. (1998). Human Rights Here and Now: Celebrating the Universal Declaration of Human Rights. Minneapolis: Human Rights USA Resource Center.

Fortat, R., and Lintaf, L. (1989). Pour Une Éducation à la Paix et Aux Droits De Lhomme. Bruxelles: Vie Ouvrière.

Freire, P. (2012). Pedagogía Del Oprimido. Barcelona: Siglo XXI.

Garnet-Russell, S., and Tiplic, D. (2014). Rights-based education and conflict: a cross-national study of rights discourse in textbooks. Comp. J. Comp. Int. Educ. 44, 314-334. doi: 10.1080/03057925.2013.765288

Gil, F., Jover, G., and Reyero, D. (2001). La Enseñanza de Los Derechos Humanos: 30 Preguntas, 29 Respuestas y 76 Actividades. Barcelona: Paidós.

Gimeno-Sacristán, J. (1991). El Curriculum, Una Reflexión Sobre la Práctica. Madrid: Morata.

Giroux, H. A. (1983). Theory and Resistance in Education: A Pedagogy for the Opposition. New York: Bergin and garvey publisher. 
Gollob, R., and Krapf, P. (2007). Exploring Children's Rights: Lesson Sequences for Primary Schools. Strasbourg: Council of Europe.

Howe, R. B., and Covell, K. (2005). Empowering Children: Children's Rights Education as a Pathway to Citizenship. Toronto: University of Toronto Press.

Howe, R. B., and Covell, K. (2010). Miseducating children about their rights. Educ. Citizenship Soc. Justice 5, 91-102. doi: 10.1177/1746197910370724

International Planned Parenthood Federation European Network (2006). Sexuality Education in Europe. A reference guide to policies and practices. Brussels: IPPF European Network.

Kulynych, J. (2001). No playing in the public sphere: democratic theory and the exclusion of children. Soc. Theory Pract. 27, 231-264. doi: 10.5840/ soctheorpract 200127211

Le Gal, J. (2008). Les Droits de l'enfant à l'école: Pour une Éducation à la Citoyenneté. Paris: De Boeck Supérieur.

Lohrenscheit, C. (2002). International approaches in HRE. Int. Rev. Educ. 48, 173-185. doi: 10.1023/A:1020386216811

López Atxurra, R., and Caba Collado, M. Á (2003). Los derechos humanos en los libros de primaria del conocimiento del medio: una estrategia de educación de la ciudadanía Íber: didáctica de las Ciencias Sociales. Geografía His. 35, 54-64.

Martínez-Bello, V. E., Cabrera García-Ochoa, Y., Díaz-Barahona, J., and Bernabé Villodre, M. D. M. (2019). Bodies in the early childhood education classroom: a Bourdieusian analysis of curricular materials. Sport Educ. Soc. doi: 10.1080/ 13573322.2019.1690442

Martínez-Bello, V. E., and Martínez-Bello, D. A. (2016). Depictions of human bodies in the illustrations of early childhood textbooks. Early Childhood Educ. J. 44, 181-190. doi: 10.1007/s10643-015-0701-x

Meintjes, G. (1997). "HRE as empowerment: reflections on pedagogy," in HRE for the Twenty-First Century, eds G. J. Andreopoulos and R. P. Claude (Philadelphia: University of Pennsylvania Press).

Merrigan, M. (2014). Education in responsibility in order to secure human rights in times of crisis. J. Soc. Sci. Educ. 13, 98-107.

Messina, C., Vanita, S., and Davies, I. (2016). "Democratic citizenship education in textbooks in Spain and England," in (Re) Constructing Memory: Textbooks, Identity, Nation, and State, eds J. H. Williams and D. Wendy (Rotterdarm: Sense Publishers). doi: 10.1007/978-94-6300-509-8_11

Meyer, J. W., Bromley, P., and Ramirez, F. O. (2010). Human rights in social science textbooks: cross-national analyses, 1970-2008. Sociol. Educ. 83, 111-134. doi: $10.1177 / 0038040710367936$

Mihr, A. (2004). Human Rights Education: Methods, Institutions, Culture and Evaluation. Discussion Papers. Magedburg: Institüt fur Politikwissenschaft Ottovon-Guericke-Universität.

Montagnes, I. (2000). Textbooks \& Learning Materials 1990-1999: A Global Survey. Paris: United Nations Educational, Scientific and Cultural Organization.

Quennerstedt, A. (2016). Young children's enactments of human rights in early childhood education. Int. J. Early Years Educ. 24, 5-18. doi: 10.1080/09669760. 2015.1096238

Quennerstedt, A., and Quennerstedt, M. (2014). Researching children's rights in education: sociology of childhood encountering educational theory. Br. J. Sociol. Educ. 35, 115-132. doi: 10.1080/01425692.2013.783962

Robinson, K. H. (2012). 'Difficult citizenship': the precarious relationships between childhood, sexuality and access to knowledge. Sexualities 15, 257-276. doi: $10.1177 / 1363460712436469$

Roose, R., and Bouverne-De Bie, M. (2007). Do children have rights or do their rights have to be realised? The United Nations convention on the rights of the child as a frame of reference for pedagogical action. J. Philos. Educ. 41, 431-443. doi: $10.1111 / j .1467-9752.2007 .00568 . x$
Sánchez-Blanco, C. (2000). De la Educación Infantil y Su Crítica: Dilemas Curriculares. Escolaridad Temprana y Discusión Ideológica. Sevilla: MCEP.

Shafer, S. M. (1987). "Human rights education in schools," in Human Rights and Education, ed. N. Bernstein-Tarrow (Oxford: Pergamon).

Smith, A. B. (2013). Understanding Children and Childhood: A New Zealand Perspective. Wellington: Bridget Williams Books. doi: 10.7810/978192713 1763

SPAIN (2007). Law ECI/390, by which Early Childhood Education is regulated [Orden ECI/3960, Por la que se establece el currículo y se regula la ordenación de la Educación Infantil]. Madrid: Ministry of Education.

Suarez, D. (2007). Professionals and the construction of human rights education comparative education review. Comp. Educ. Rev. 51, 48-70. doi: 10.1086/ 508638

Tibbitts, F. (2002). Understanding what we do: emerging models for HRE. Int. Rev. Educ. 48, 159-171. doi: 10.1023/A:1020338300881

Tomaševski, K. (2001). Human Rights in Education as Prerequisite for HRE. Lund: Raoul Wallenberg Institute of Human Rights and Humanitarian Law.

Unal, F. (2013). Children's rights in life sciences textbooks in primary education in Turkey. Educ. Res. Rev. 8, 1470-1476.

United Nations (1989). Convention on the Rights of the Child. General Assembly Resolution 44/25. 20 November. UN Doc. A/RES/44/25. New York, NY: United Nations.

United Nations (1993). Vienna Declaration and Programme of Action. General Assembly Resolution A/RES/48/121. New York, NY: United Nations.

United Nations (2006). Committee on the Rights of the Child. General Comment No. 7 Implementing child rights in early childhood. 20 September. UN Doc. CRC/C/GC/7/Rev.1. New York, NY: United Nations.

United Nations (2011). United Nations Declaration on Human Rights Education and Training. General Assembly Resolution 66/137. 19 December. UN Doc. A/RES/66/137. New York, NY: United Nations.

United States (2004). Sexuality Information and Education Council of the United States. Guidelines for Comprehensive Sexuality Education. New York, NY: Fulton Press.

Waldron, F., and Oberman, R. (2016). Responsible citizens? How children are conceptualised as rights holders in Irish primary schools. Int. J. Hum. Rights 20, 744-760. doi: 10.1080/13642987.2016.1147434

Weinbrenner, P., and Fritzsche, K. P. (1993). Teaching Human Rights: Suggestions for Teaching Guidelines. Bonn: German Commission for Unesco.

Woodrow, C., and Press, F. (2007). (Re) positioning the child in the policy/politics of early childhood. Educ. Philos. Theory 39, 312-325. doi: 10.1111/j.1469-5812. 2007.00328.x

Conflict of Interest: The authors declare that the research was conducted in the absence of any commercial or financial relationships that could be construed as a potential conflict of interest.

Copyright (อ 2020 Martínez-Bello, Martínez-Rojas and Lahuerta-Contell. This is an open-access article distributed under the terms of the Creative Commons Attribution License (CC BY). The use, distribution or reproduction in other forums is permitted, provided the original author(s) and the copyright owner(s) are credited and that the original publication in this journal is cited, in accordance with accepted academic practice. No use, distribution or reproduction is permitted which does not comply with these terms. 